\title{
TINJAUAN RISET MAHASISWA PROGRAM STUDI MAGISTER MANAJEMEN PENDIDIKAN ISLAM PASCASARJANA UIN ALAUDDIN MAKASSAR (Analisis Kecenderungan dan Bidang Kajian Penelitian Mahasiswa)
}

\author{
SITI SYAMSUDDUHA, AYU RUQAYYAH YUNUS, DANIAL RAHMAN \\ Universitas Islam Negeri Alauddin Makassar \\ Email: st.syamsudduha@uin-alauddin.ac.id, ayu.ruqayyah@uin-alauddin.ac.id, \\ danial.rahmaan@gmail.com \\ (Article History) \\ Received December 01, 2020; Revised December 10, 2020; Accepted December 13, 2020
}

\begin{abstract}
:
This article aims to describe: (1) Student research trends in terms of themes, fields of study, and methodology; (2) Suitability between research and the student's field of science; and (3) The basis for determining the field of research of students of the Master of Islamic Education Management Study Program at UIN Alauddin Makassar. This research is quantitative descriptive. The samples were determined based on the purposive sampling technique, namely students who had completed their studies were 85 people. The data techniques used were documentation and interviews. Then the results were analyzed through descriptive statistics and supported by interview results. The results showed that: (1) Student research trends, including: (a) tended to be on the theme of schools, madrasah and boarding school; (b) tends to organizational behavior, SBM, and leadership; (c) tends to use a qualitative approach; (2) Students have adjusted their research studies to the field of educational management; and (3) The basis for determining the student's field of study is motivated by its suitability with the field of work, experience in lectures and the work environment, as well as that of a general nature.
\end{abstract}

Keywords: Research, Study Field, Education Management, Postgraduate Students

\section{PENDAHULUAN}

Denelitian dan ilmu pengetahuan bagaikan dua sisi dari satu mata uang, penelitian dan ilmu pengetahuan tidak bisa dipisahkan karena penelitian ilmiah digunakan untuk kebutuhan ilmu pengetahuan. Sebaliknya, ilmu pengetahuan tidak akan berkembang apabila meninggalkan tradisi penelitian ilmiah. Penelitian sebagai sistem ilmu pengetahuan memainkan peran penting dalam bangunan ilmu pengetahuan itu sendiri. Hal ini mengindikasikan bahwa penelitian telah menempati posisi yang paling urgen dalam ilmu pengetahuan untuk melindunginya dari kepunahan. Bungin (2014) mengemukakan bahwa penelitian memiliki kemampuan untuk meng-update ilmu pengetahuan yang membuat up-todate dan canggih dalam aplikasi serta setiap saat dibutuhkan masyarakat. 
Penelitian merupakan serangkaian aktivitas yang dilakukan dalam rangka mengumpulkan data-data kemudian diolah, baik secara kualitatif maupun kuantitatif. Sukmadinata (2013) memberikan argumentasinya bahwa penelitian dilakukan karena pengetahuan, pemahaman, dan kemampuan manusia sangat terbatas sehingga selalu memiliki motivasi untuk mengetahui. Selain itu, manusia selalu dihadapkan kepada masalah, tantangan, ancaman, kesulitan dalam kehidupannya, serta manusia selalu memiliki rasa tidak puas dengan apa yang telah dikuasai dan dimilikinya karena selalu memiliki keinginan yang lebih baik, serta ingin menambah dan meningkatkan "kekayaan" dan fasilitas hidupnya. Oleh karena itu, penelitian terus berkembang dan berlanjut secara terus menerus.

Kegiatan penelitian adalah suatu proses pengumpulan data yang sistematis dan analisis yang logis terhadap informasi (data) untuk tujuan tertentu. Saat dan Mania (2019) menyatakan bahwa suatu penelitian ilmiah akan melahirkan kebenaran ilmiah, yaitu kebenaran yang dapat dipertanggungjawabkan dengan menggunakan kaidah-kaidah ilmiah yang meliputi rasional, sistematik, dapat diobservasi, dieksperimen, dan berdasarkan fakta empirik. Hal ini sesuai dengan ungkapan Furchan (2007, h. 32) bahwa "Penelitian ilmiah merupakan penerapan pendekatan ilmiah pada pengkajian suatu masalah atau cara untuk memperoleh informasi yang berguna dan dapat dipertanggungjawabkan dengan tujuan untuk menemukan jawaban terhadap persoalan yang berarti, melalui penerapan prosedurprosedur ilmiah". Yusuf (2014) memberikan penjelasan bahwa penelitian pada awalnya muncul karena adanya rasa ingin tahu manusia terhadap fenomenafenomena yang terjadi di sekitarnya. Manusia dalam kesehariannya selalu ingin tahu yang ditopang oleh kondisi psikologis yang dimilikinya, matra kognitif dan afektif yang mendorongnya untuk selalu berupaya dan berperilaku. Manusia mungkin tahu tentang sesuatu dan sadar akan keberadaannya, namun realitas di masyarakat tidak selamanya sesuai dengan yang dipikirkannya, sehingga mengundang mereka untuk menghayati sesuatu yang memiliki keganjilan, sesuatu jurang (gap) antara yang terjadi dan yang seharusnya.

Keinginan manusia untuk mengetahui fakta yang terjadi mendorong mereka untuk menyelidiki, menemukan, memecahkan masalah tersebut, atau mencari kebenaran keilmuan tentang sesuatu. Meskipun rasa ingin menyelidiki secara implisit berada dalam diri manusia, sebagai makhluk rasional manusia mempunyai keterbatasan dalam kadar potensi yang mereka miliki. Keterbatasan manusia tersebut bersumber dari keterbatasannya sebagai makhluk ciptaan Tuhan. Sejarah telah menunjukkan bahwa manusia di muka bumi ini dengan keterbatasannya selalu berusaha mencari dan menemukan sesuatu yang baru. Mereka berusaha mencari, menemukan, menggali, menyelidiki, dan menganalisis sesuatu dengan tekun dan teliti. Hasrat ingin tahu manusia terhadap fenomena tersebutlah yang akan melahirkan keinginan untuk melakukan penelitian, sebagaimana dikemukakan oleh Misbahuddin dan Hasan (2013, h. 4) bahwa "Penelitian merupakan penyaluran rasa 
ingin tahu manusia terhadap sesuatu/masalah dengan perlakuan tertentu, sehingga diperoleh sesuatu (seperti mencapai kebenaran, memperoleh jawaban atas masalah, pengembangan ilmu pengetahuan, dan sebagainya)". Berdasarkan ungkapan tersebut, penelitian memiliki empat komponen, yaitu ada rasa ingin tahu manusia, ada sesuatu/masalah, ada proses atau usaha untuk menyelesaikan sesuatu/masalah, dan ada hasilnya (seperti mencapai atau menemukan kebenaran).

Tantangan dan tuntutan masyarakat yang bertambah kompleks di lingkungannya membuat manusia tidak terbebas dari berbagai masalah. Sering terjadi jurang (gap) antara harapan dan realitas dalam masyarakat, atau antara apa yang seharusnya dan apa yang ada dalam masyarakat. Masalah-masalah yang timbul tidak hanya timbul di lingkungan masyarakat, tetapi juga di lingkungan organisasi, tidak terkecuali dalam lembaga pendidikan. Lembaga pendidikan sebagai wadah untuk memproses peserta didik dalam mempersiapkan memasuki kehidupan yang sesungguhnya melalui pemberian ilmu pengetahuan tidak terlepas dari berbagai persoalan yang dihadapinya, terutama dari segi manajemennya. Oleh karena itu, masalah-masalah dalam manajemen pendidikan tersebut akan mengundang rasa ingin tahu dari kalangan ilmuwan manajemen untuk menyelidiki permasalahan tersebut.

Permasalahan dalam manajemen pendidikan, khususnya manajemen pendidikan Islam sangat banyak dijumpai, sehingga membutuhkan pemecahanpemecahan yang intens. Oleh karena itu, para peneliti (dosen maupun mahasiswa dalam lingkup keilmuan manajemen pendidikan) akan berupaya melakukan penyelidikan atau penelitian untuk menggali permasalahan-permasalahan tersebut. Masalah manajemen dalam lembaga pendidikan merupakan tugas dosen dan Mahasiswa Program Studi Manajemen Pendidikan Islam untuk menggali dan menyelidiki permasalahan-permasalahan tersebut melalui kegiatan penelitian.

Penyusunan karya ilmiah menggunakan metode ilmiah, bahasa baku, tata tulis ilmiah, dan prinsip-prinsip keilmuan. Saebani (2017) menyatakan bahwa prinsipprinsip keilmuan yang bersifat objektif, logis, empiris, sistematis, lugas, jelas, konsisten, dan profesional. Setiap ilmu memiliki ciri dan kekhususannya masingmasing, meskipun antara yang satu dengan yang lainnya dapat saling berkaitan. IImu manajemen sebagai bagian dari kekayaan pengetahuan manusia memiliki ciri dan kekhususan sendiri pula yang dapat membedakannya dengan ilmu pengetahuan lainnya, baik secara ontologi, epistemologi, maupun aksiologi. Dengan demikian, setiap kajian tentang metode keilmuan tertentu harus terlebih dahulu menjawab tiga (3) pertanyaan, yaitu apa bahan yang akan dikaji?, bagaimana cara mengkajinya?, dan apa manfaat atau tujuan dilakukannya kajian tersebut?. Ketiga pertanyaan tersebut harus terjawab dalam setiap kajian keilmuan, termasuk kajian ilmu manajemen pendidikan. 
Lingkup bidang kajian penelitian manajemen pendidikan menurut Mahmud (2011, h. 69) dibedakan menjadi dua bagian, yaitu lingkup manajemen pendidikan teoretis dan lingkup manajemen pendidikan teoretis praktis. Lingkup manajemen pendidikan teoretis, mencakup teori manajemen, teori kepemimpinan, teori kebijakan, teori perencanaan, dan teori pengendalian atau penjaminan. Adapun lingkup manajemen pendidikan teoretis praktis dikelompokkan menjadi enam (6) bagian, yaitu: (1) Kepemimpinan, yaitu kegiatan yang dilakukan untuk memberikan pengaruh kepada orang lain untuk mengikuti dan melaksanakan kegiatan sesuai yang diharapkan; (2) Model-model manajemen, meliputi management by objective, technology based management, school based management, community based management, dan centralized-decentralized management; (3) Proses manajemen, yaitu kajian terhadap manajemen pendidikan dapat dilakukan melalui perencanaan, penyusunan staf, pengorganisasian, penggerakan, pengoordinasian, pengomunikasian, pengendalian atau penjaminan, pengawasan atau pembinaan, evaluasi, dan pelaporan; (4) Komponen atau segi yang dikelola, yaitu kajian yang dikelola dapat melalui manajemen kurikulum, manajemen pembelajaran, dan manajemen evaluasi; (5) Komponen pendidikan, meliputi manajemen pembinaan peserta didik atau mahasiswa, manajemen penelitian dan pengembangan, manajemen kerja sama dan pelayanan pada masyarakat, manajemen personal, manajemen sarana dan prasarana, manajemen media dan sumber belajar, serta manajemen keuangan; dan (6) Lingkup pendidikan, yaitu pendidikan dapat dilakukan dengan melihat beberapa lingkup pendidikan, seperti manajemen sekolah, manajemen pendidikan luar sekolah, manajemen pendidikan dasar, manajemen pendidikan menengah, manajemen pendidikan tinggi, serta manajemen pendidikan lingkup dinas.

Tugas penelitian merupakan salah satu dari tri dharma perguruan tinggi, sebagaimana dikemukakan oleh Suryabrata (2016, h. 1) bahwa “Perguruan tinggi di Indonesia mengemban tiga dharma perguruan tinggi, yaitu tugas pendidikan, tugas penelitian, dan tugas pengabdian kepada masyarakat". Dalam usaha meningkatkan suasana akademik di kampus serta dalam upaya memandu penyajian pengalaman belajar yang menumbuhkan sikap, kemampuan, dan keterampilan meneliti pada mahasiswa, metodologi penelitian merupakan hal yang esensial. Dalam melakukan sesuatu (termasuk penelitian), seseorang harus memiliki motivasi yang kuat. Danial, dkk. (2019, h. 143) menyatakan bahwa "Suatu prestasi tidak mudah diraih oleh seseorang, melainkan melalui usaha dan kerja keras yang dibarengi dengan motivasi dan optimisme yang tinggi". Lebih lanjut, (Rahman dan Husain, 2020) menyatakan bahwa kuat lemahnya motivasi seseorang akan menentukan besar kecilnya prestasi yang dicapai. Pernyataan tersebut juga berlaku dalam melakukan penelitian ilmiah. Oleh karena itu, setiap mata kuliah diharapkan dapat menimbulkan kegairahan untuk meneliti, sehingga di samping mengembangkan penguasaan materi, mata 
kuliah diharapkan juga dapat memberikan pengalaman belajar yang menumbuhkan sikap, kemampuan, dan keterampilan meneliti pada mahasiswa.

Ada berbagai macam penelitian yang biasa dilakukan. Jika ditinjau dari segi pendekatannya dapat dibedakan menjadi metode penelitian kuantitatif dan kualitatif. Sugiyono (2016) mengemukakan bahwa metode penelitian kuantitatif merupakan metode penelitian yang berlandaskan pada filsafat positivism, digunakan untuk meneliti populasi atau sampel tertentu, pengumpulan data menggunakan instrumen penelitian, analisis bersifat kuantitatif/statistik, dengan tujuan untuk menguji hipotesis yang telah ditetapkan. Adapun metode penelitian kualitatif merupakan metode penelitian yang berlandaskan filsafat postpositivisme, digunakan untuk meneliti pada kondisi objek alamiah, peneliti sebagai instrumen kunci, teknik pengumpulan data dilakukan secara triangulasi, analisis data bersifat induktif, dan hasil penelitian lebih menekankan makna daripada generalisasi.

Menulis karya ilmiah sudah menjadi rutinitas warga kampus di perguruan tinggi seluruh pelosok dunia, tidak terkecuali warga kampus UIN Alauddin Makassar, salah satu perguruan tinggi yang diisi oleh mahasiswa dan dosen pada berbagai jurusan mewajibkan mereka melakukan salah satu dari tri darma perguruan tinggi, yaitu melakukan penelitian. Mardiana (2013) menjelaskan bahwa setiap mahasiswa yang akan menyelesaikan studinya pada jenjang tertentu diharuskan membuat satu karya ilmiah dalam bentuk laporan penelitian, berupa skripsi, tesis atau disertasi. Untuk menunjang penyelesaian studinya, mahasiswa harus melakukan penelitian, baik penelitian lapangan, penelitian pustaka maupun penelitian laboratorium. Oleh karena itu, perlu adanya perhatian intensif terhadap penguatan metodologi penelitian mahasiswa. Prahmana, dkk. (2016) menyatakan bahwa sintaks model pembelajaran berbasis riset memiliki peran yang besar dalam menumbuhkan keterampilan meneliti. Lintasan belajar yang dihasilkan adalah lintasan belajar yang dilalui mahasiswa dalam upaya menumbuhkan keterampilan dalam melakukan penelitiannya.

Penelitian-penelitian sebelumnya tentang tinjauan karya ilmiah mahasiswa juga telah dilakukan, seperti halnya Pujiyanto dan Suyoso (2011) yang menyimpulkan bahwa isu-isu yang paling banyak diteliti oleh mahasiswa Prodi Pendidikan Fisika selama lima tahun terakhir adalah model dan metode pembelajaran dan isu-isu pendidikan yang masih memungkinkan diteliti lebih lanjut adalah laboratorium, life skills dan keterampilan berpikir peserta didik.

Lebih lanjut, Ardiansyah, dkk. (2013) yang menemukan bahwa tema yang dijadikan topik penulisan skripsi oleh mahasiswa jurusan PHM tahun 2008-2012 adalah Ibadah, Perdata, Pidana, Thaharah, Ushul Figh dan Pengadilan. Selain itu, Nugroho (2016) melalui hasil penelitiannya menyimpulkan bahwa mahasiswa Pendidikan Biologi FKIP UMS yang lulus tahun 2015 memiliki kecenderungan memilih bidang penelitian terapan, pendekatan penelitian kualitatif, metode eksperimen, serta jenjang sekolah SMP yang dijadikan fokus dalam penelitian 
pendidikan. Penelitian-penelitian sebelumnya tersebut memiliki relevansi dengan penelitian ini karena sama-sama menelaah dan menganalisis tema tentang riset yang dilakukan oleh mahasiswa. Meskipun demikian, penelitian-penelitian tersebut tentu memiliki perbedaan dengan penelitian ini, terutama dari segi jenis riset mahasiswa yang diteliti, tingkatan mahasiswa yang diteliti, program studi mahasiswa, dan metodologi penelitian yang digunakan untuk membedah kecenderungan riset mahasiswa tersebut, serta belum terdapat penelitian secara khusus menelaah tinjauan tentang tugas akhir mahasiswa Prodi Manajemen Pendidikan Islam.

Pada praktiknya, pelaksanaan penelitian tidak terlepas dari berbagai persoalan, baik dari segi rancangan, metodologi, sampai kepada pelaksanaannya. Wendra dkk. (2014) menyatakan bahwa "Kenyataan menunjukkan, hambatan sebagian besar mahasiswa dalam menyelesaikan studinya di perguruan tinggi di antaranya disebabkan oleh kesulitan menyusun karya ilmiah (skripsi, tesis, disertasi)". Masalah yang paling sering dialami mahasiswa adalah kesulitan dalam menemukan dan menentukan masalah yang akan diteliti. Banyak mahasiswa yang beranggapan bahwa yang ditentukan pertama kali adalah judul penelitian, bukan masalah penelitian. Mahasiswa tingkat akhir (semester 7 ke atas untuk mahasiswa S-1 dan semester 3 ke atas untuk mahasiswa pascasarjana) selalu menyibukkan diri untuk mencari judul penelitian yang akan menjadi kajian dalam penelitiannya, bukan mencari dan mengidentifikasi masalah yang terjadi di lapangan (di lembaga pendidikan maupun di instansi non pendidikan).

Faktor kesibukan dalam menentukan judul penelitian tersebut mengakibatkan banyak mahasiswa yang bingung dalam menentukan rumusan masalah penelitian karena mereka menentukan judul tanpa mengetahui masalahnya, sehingga tidak jarang ditemukan mahasiswa yang membuatkan masalah sendiri terhadap judul penelitiannya. Fenomena tersebut tidak hanya dialami oleh peneliti pemula seperti mahasiswa S-1, tetapi sering juga dialami oleh mahasiswa S-2, bahkan S-3 sekalipun di semua perguruan tinggi, termasuk UIN Alauddin Makassar.

Mahasiswa pada hakikatnya, termasuk mahasiswa UIN Alauddin Makassar di setiap tingkatannya, baik S-1, S-2, maupun S-3 memiliki ketentuan penelitian yang akan dilakukan, yaitu harus sesuai dengan bidang ilmu yang dikaji oleh masingmasing mahasiswa. Akan tetapi, pada realitasnya masih banyak mahasiswa yang cenderung sulit menentukan batas kajian keilmuannya, termasuk mahasiswa Program Studi Magister Manajemen Pendidikan Islam Pascasarjana UIN Alauddin Makassar. Oleh karena itu, penelitian ini akan menelaah tentang profil riset mahasiswa Program Studi Magister Manajemen Pendidikan Islam Pascasarjana UIN Alauddin makassar untuk melihat kecenderungan dan bidang kajian penelitian mahasiswa. Kecenderungan yang dimaksud adalah kecenderungan dalam memilih tema, bidang kajian, metodologi, kesesuaian bidang kajian dengan bidang ilmu mahasiswa, serta dasar penentuan tema dan bidang kajian penelitian mahasiswa. 
Penelitian ini diharapkan dapat menggambarkan tema-tema yang dipilih mahasiswa, begitu pula kecenderungan metode yang digunakan dalam penelitian tesisnya. Hasil penelitian ini juga diharapkan dapat memberi rekomendasi terkait proses perkuliahan dan pembimbingan tesis agar mahasiswa Program Studi Magister Manajemen Pendidikan Islam melakukan penelitian sesuai dengan bidang keilmuan manajemen pendidikan.

\section{METODE PENELITIAN}

Penelitian ini merupakan field research atau penelitian yang dilakukan untuk mengumpulkan data atau informasi yang diperoleh langsung dari lapangan atau responden. Pendekatan yang digunakan adalah quantitative descriptive yang dilakukan pada Program Studi Magister Manajemen Pendidikan Islam di Pascasarjana UIN Alauddin Makassar. Populasi yang menjadi subjek dalam penelitian ini, yaitu semua mahasiswa Program Studi Magister Manajemen Pendidikan Islam Pascasarjana UIN Alauddin Makassar sebanyak 161 orang mahasiswa. Penentuan sampel dalam penelitian ini dilakukan dengan menggunakan teknik purposive sampling, dengan pertimbangan bahwa sampel yang ditentukan hanya mahasiswa Prodi Magister MPI yang telah menyelesaikan studinya, karena merekalah yang telah menghasilkan karya ilmiah berupa tesis. Dengan demikian, sampel dalam penelitian ini adalah semua mahasiswa Prodi Magister MPI Pascasarjana UIN Alauddin Makassar yang telah menyelesaikan studinya yang berjumlah 85 orang dari tahun 2016-2019.

Teknik pengumpulan data yang digunakan dalam penelitian ini adalah dokumentasi dan wawancara. Teknik pengumpulan data melalui studi dokumentasi digunakan untuk menghimpun data berupa dokumen atau tesis-tesis mahasiswa Prodi Magister Manajemen Pendidikan Islam Pascasarjana UIN Alauddin Makassar. Selain itu, pengecekan tentang kecenderungan dan dasar pemilihan tema riset mahasiswa juga melalui wawancara kepada alumni yang dijadikan sampel. Instrumen yang digunakan untuk mengumpulkan data dalam penelitian ini, yaitu format catatan dokumen dan pedoman wawancara. Format catatan dokumen ini berisi tentang hal-hal yang dibutuhkan dari tesis mahasiswa Prodi Magister Manajemen Pendidikan Islam Pascasarjana UIN Alauddin Makassar. Pedoman wawancara berisikan garis besar pertanyaan yang akan diajukan kepada informan.

Data yang diperoleh dalam penelitian ini diolah dengan mengorganisasikan data berdasarkan kecenderungan mahasiswa pada tiap aspek, mulai dari kecenderungan dalam memilih tema penelitian, kesesuaian bidang kajian dengan masalah yang diteliti, kecenderungan pemilihan jenis penelitian, pendekatan penelitian, kesesuaian metodologi dengan masalah yang diteliti, kesesuaian riset dengan bidang manajemen pendidikan Islam, serta dasar penentuan tema dan bidang kajian mahasiswa. Data yang telah diolah kemudian dianalisis dengan menggunakan analisis kuantitatif melalui statistik deskriptif. 


\section{HASIL PENELITIAN DAN PEMBAHASAN}

\section{Kecenderungan Riset Mahasiswa Program Studi Magister Manajemen Pendidikan} Islam Pascasarjana UIN Alauddin Makassar

Kecenderungan riset mahasiswa Program Studi Magister Manajemen Pendidikan Islam Pascasarjana UIN Alauddin Makassar dilakukan dengan menganalisis kecenderungan tema penelitian, bidang kajian, dan kecenderungan metodologi penelitian. Masing-masing kecenderungan tersebut dianalisis untuk melihat arah kecenderungan penelitian mahasiswa Program Studi Magister Manajemen Pendidikan Islam Pascasarjana UIN Alauddin Makassar.

\section{Kecenderungan Tema Penelitian}

Tema penelitian yang dimaksud dalam penelitian ini merupakan aspek penentuan lokasi yang dipilih mahasiswa sebagai tempat untuk meneliti fenomenafenomena sebagai bentuk kepedulian dan perhatiannya terhadap masalah-masalah atau isu-isu yang sedang berkembang terkait bahan kajian manajemen pendidikan Islam. Arah tema penelitian alumni Magister Manajemen Pendidikan Islam dalam penelitian ini diklasifikasikan menjadi 5 bagian, yaitu sekolah, madrasah, pesantren, perguruan tinggi, dan instansi lain. Deskripsi tentang arah tema penelitian yang dilakukan oleh mahasiswa (alumni) 2016-2019 dapat dilihat pada diagram berikut:

\section{Gambar 1. Diagram Batang Arah Tema Penelitian Mahasiswa}

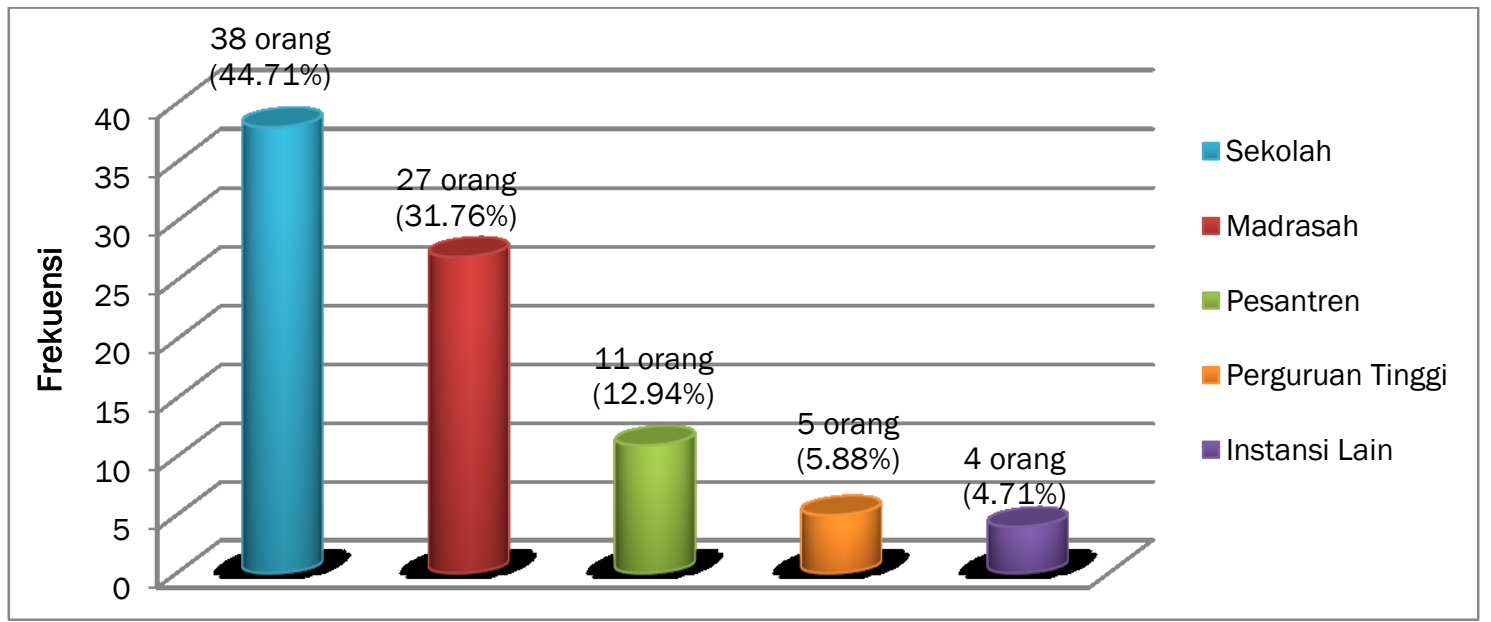

Sumber: Data diolah, 2020

Berdasarkan data yang telah disajikan pada Gambar 1, dapat diketahui bahwa dari 85 mahasiswa yang telah melakukan penelitian, kebanyakan mahasiswa memilih tema penelitian pada sekolah dan madrasah dibandingkan dengan pesantren, perguruan tinggi, maupun lembaga yang sifatnya non pendidikan atau yang tidak melaksanakan kegiatan pembelajaran di dalamnya. Hasil penelitian menunjukkan bahwa 44,71\% mahasiswa memilih tema penelitiannya pada sekolah, 31,76 pada madrasah, $12,94 \%$ pada pesantren, 5,88\% pada perguruan tinggi, dan hanya 4,71\% mahasiswa memilih pada instansi lain di luar lembaga pendidikan. Padahal, ranah kajian manajemen pendidikan tidak hanya dibatasi pada lembaga 
pendidikan formal yang di dalamnya melaksanakan kegiatan pembelajaran secara terstruktur dan berjenjang, tetapi juga dapat melakukan penelitian pada lembaga pendidikan informal dan nonformal maupun organisasi-organisasi umum lainnya. Data yang diperoleh menunjukkan bahwa hanya 4 orang mahasiswa yang melakukan penelitian di luar lembaga pendidikan, yaitu pada Kantor Kementerian Agama yang merupakan kantor pelayanan publik pada setiap kabupaten. Hal tersebut menandakan kecenderungan mahasiswa dalam memilih arah tema penelitian lebih kepada lembaga pendidikan formal, seperti sekolah, madrasah, pesantren, dan perguruan tinggi.

\section{Kecenderungan Bidang Kajian}

Bidang kajian merupakan bidang keilmuan manajemen pendidikan yang dipilih sebagai landasan teoretis dalam membedah fenomena yang dijadikan latar penelitian. Kecenderungan mahasiswa dalam bidang kajian penelitian dapat diidentifikasi berdasarkan fokus penelitian dan variabel penelitian yang dipilih oleh mahasiswa. Kecenderungan tersebut dapat dideskripsikan pada diagram berikut:

\section{Gambar 2. Diagram Lingkaran Persentase Kecenderungan dalam Bidang Kajian Penelitian Mahasiswa}

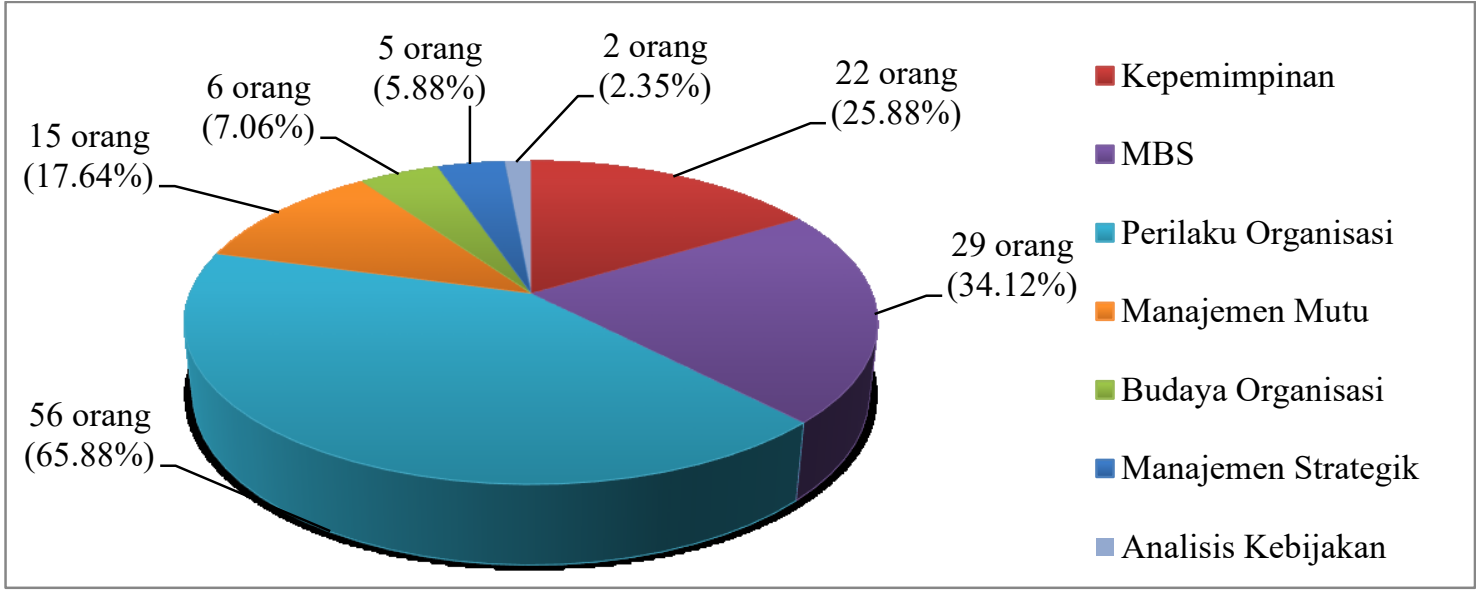

Sumber: Data diolah, 2020

Berdasarkan data yang telah disajikan pada Gambar 2, dapat diketahui bahwa dari 85 mahasiswa yang telah melakukan penelitian, kebanyakan mahasiswa memilih bidang kajian terkait perilaku organisasi dibandingkan dengan bidang kajian lainnya dengan persentase sebesar $65,88 \%$. Bidang manajemen berbasis sekolah sebesar $34,12 \%$, bidang kepemimpinan sebesar $25,88 \%$, bidang manajemen mutu sebesar $17,64 \%$, bidang budaya organisasi sebesar 7,06\% dan bidang keilmuan dengan persentase terkecil yang dipilih mahasiswa adalah bidang manajemen strategik dan analisis kebijakan, masing-masing sebesar 5,88\% dan 2,35\%. Data yang diperoleh tersebut menunjukkan bahwa manajemen strategik dan analisis kebijakan menempati posisi paling sedikit yang dijadikan kajian penelitian oleh mahasiswa. Hal ini menandakan bahwa mahasiswa lebih cenderung menelaah 
fenomena-fenomena terkait perilaku organisasi, manajemen berbasis sekolah, dan kepemimpinan.

\section{Kecenderungan Metodologi Penelitian}

Kecenderungan mahasiswa dalam metodologi penelitian meliputi kecenderungan jenis penelitian berdasarkan pendekatan penelitian yang digunakan dan aspek kesesuaian antara metodologi penelitian dengan masalah yang diteliti. Jenis penelitian yang dipilih oleh mahasiswa yang telah menyelesaikan studinya 4 tahun terakhir (2016-2019) berdasarkan data yang diperoleh dengan melihat jenis berdasarkan pendekatannya dapat diklasifikasikan menjadi 2 jenis penelitian. Kedua jenis penelitian ditentukan berdasarkan pendekatannya, karena semua tema yang dipilih oleh mahasiswa berbasis field research atau penelitian lapangan. Kedua jenis penelitian tersebut dapat dideskripsikan sebagai berikut:

Tabel 1. Distribusi Frekuensi Kecenderungan Pendekatan Penelitian Mahasiswa

\begin{tabular}{c|l|c|c}
\hline No & \multicolumn{1}{|c|}{ Kecenderungan Mahasiswa } & Frekuensi & Persentase \\
\hline 1 & Kuantitatif & 32 & $37.65 \%$ \\
2 & Kualitatif & 53 & $62.35 \%$ \\
\hline \multicolumn{2}{r|}{ Jumlah } & 85 & $100 \%$ \\
\hline
\end{tabular}

Sumber: Data diolah, 2020

Tabel 1 menunjukkan jumlah frekuensi dan persentase kecenderungan mahasiswa dalam menentukan jenis penelitian yang dilakukannya. Berdasarkan data yang telah disajikan dalam tabel tersebut, dapat diketahui bahwa dari 85 mahasiswa yang telah melakukan penelitian, kebanyakan mahasiswa memilih jenis penelitian kualitatif dengan menganalisis fenomena-fenomena dan kasus-kasus yang terjadi pada lokasi tempat mereka melakukan penelitian, yaitu sebesar $62,35 \%$, sedangkan penelitian kuantitatif yang di dalamnya mencakup penelitian survey dan ex post facto sebesar $37,65 \%$ dari total mahasiswa yang menyelesaikan studinya mulai dari 2016-2019. Data yang diperoleh tersebut menunjukkan bahwa jenis penelitian kualitatif lebih dominan menjadi pilihan mahasiswa dibandingkan dengan penelitian kuantitatif.

Hasil wawancara dengan beberapa alumni tentang kecenderungannya memilih jenis penelitian dengan pendekatan kualitatif didasarkan karena kurangnya pemahaman tentang statistik dan adanya "ketakutan" dengan pengolahan angkaangka menggunakan rumus statistik, seperti dikemukakan oleh beberapa alumni bahwa "Pemilihan jenis penelitian kualitatif ini didasarkan karena kurangnya pemahaman kami tentang statistik, sementara penelitian kuantitatif tidak terlepas dari angka-angka yang mengharuskan pengolahan data secara statistik. Penelitian kuantitatif agak susah karena yang dianalisis adalah angka kemudian diinterpretasi". Mahasiswa dalam menentukan jenis dan pendekatan penelitiannya masing-masing memiliki alasan yang kongkret. Akan tetapi, jenis penelitian yang lebih banyak dipilih oleh mahasiswa adalah jenis dengan pendekatan kualitatif. Hal 
ini menandakan bahwa mahasiswa lebih cenderung memilih jenis penelitian kualitatif dalam melihat atau menelaah fenomena tentang manajemen pendidikan yang terjadi di lapangan, baik di sekolah, madrasah, pesantren, perguruan, tinggi, maupun instansi lainnya.

Kesesuaian antara metodologi dengan masalah yang diteliti mahasiswa dapat dianalisis melalui kesesuaian judul penelitian, rumusan masalah, dengan metode penelitian yang digunakan oleh mahasiswa. Metodologi penelitian yang penggunaannya keliru di kalangan mahasiswa adalah penggunaan jenis penelitian yang ditinjau dari berbagai aspek, pendekatan keilmuan yang digunakan, teknik dan instrumen, serta teknik analisis yang digunakan. Kesesuaian metodologi penelitian dengan masalah yang diteliti oleh mahasiswa tersebut dapat disajikan dalam tabel berikut:

Tabel 2. Kesesuaian Metodologi dengan Masalah yang Diteliti Mahasiswa

\begin{tabular}{c|l|c|c}
\hline No & \multicolumn{1}{|c|}{ Kecenderungan Mahasiswa } & Frekuensi & Persentase \\
\hline 1 & Sesuai & 69 & $81.18 \%$ \\
2 & Tidak Sesuai & 16 & $18.82 \%$ \\
\hline \multicolumn{2}{c|}{ Jumlah } & 85 & $100 \%$ \\
\hline
\end{tabular}

Sumber: Data diolah, 2020

Tabel 2 menunjukkan jumlah frekuensi dan persentase kesesuaian antara metodologi dengan masalah yang diteliti oleh mahasiswa. Berdasarkan data yang telah disajikan pada Tabel 2, dapat diketahui bahwa dari 85 mahasiswa yang telah melakukan penelitian, $81,18 \%$ mahasiswa sudah menyesuaikan masalah yang diteliti dengan metodologi penelitiannya, tetapi masih terdapat 18,82\% mahasiswa yang belum menyesuaikan metodologi penelitiannya dengan masalah yang ditelitinya. Hasil temuan yang diperoleh terkait ketidaksesuaian tersebut, meliputi: kesalahan dalam menentukan jenis penelitian; penggunaan pendekatan keilmuan yang cenderung terkesan sebagai "pajangan" pendekatan, tetapi tidak terlihat penggunaannya pada hasil penelitian; penetapan teknik dan instrumen penelitian yang dicantumkan pada metodologi penelitian, tetapi pada prosesnya tidak digunakan; teknik analisis yang digunakan, dan ketidaksesuaian antara objek yang diteliti dengan subjek yang dijadikan informan (responden). Hal ini menandakan bahwa masih terdapat beberapa mahasiswa yang belum memahami secara jelas terkait metodologi penelitian, terutama dalam menyesuaikan antara masalah dengan metode yang digunakan.

Kesesuaian Riset dengan Bidang IImu Mahasiswa Program Studi Magister Manajemen Pendidikan Islam Pascasarjana UIN Alauddin Makassar

Mahasiswa Manajemen Pendidikan Islam dalam melakukan penelitian hendaknya tidak melenceng atau keluar dari bidang kajian penelitian manajemen pendidikan, seperti kepemimpinan, perilaku organisasi, analisis kebijakan, manajemen berbasis sekolah, budaya organisasi, manajemen strategik, dan manajemen mutu. Bidang-bidang kajian tersebut harus dipahami dengan baik oleh 
Mahasiswa Program Studi Manajemen Pendidikan agar tema dan masalah yang dipilih dalam penelitiannya tidak keluar dari manajemen pendidikan itu sendiri. Hasil penelitian terkait kesesuaian riset dengan bidang kajian yang dilakukan oleh Mahasiswa Program Studi Magister Manajemen Pendidikan Islam UIN Alauddin Makassar pada 4 tahun terakhir (2016-2019) dapat dideskripsikan sebagai berikut:

Tabel 3. Kesesuaian Bidang IImu yang Diteliti Mahasiswa

\begin{tabular}{c|l|c|c}
\hline No & \multicolumn{1}{|c|}{ Kecenderungan Mahasiswa } & Frekuensi & Persentase \\
\hline 1 & Sesuai & 84 & $98.82 \%$ \\
2 & Tidak Sesuai & 1 & $1.18 \%$ \\
\hline \multicolumn{2}{c|}{ Jumlah } & 85 & $100 \%$ \\
\hline
\end{tabular}

Sumber: Data diolah, 2020

Tabel 3 menunjukkan jumlah frekuensi dan persentase mahasiswa yang memiliki kesesuaian dan ketidaksesuaian antara riset yang dilakukan dengan bidang kajian manajemen pendidikan. Berdasarkan data yang telah disajikan tersebut, dapat diketahui bahwa dari 85 mahasiswa yang telah melakukan penelitian, hampir semua mahasiswa atau 98,82\% yang telah menyesuaikan dengan bidang keilmuan manajemen pendidikan, dan hanya 1 orang atau 1,18\% mahasiswa yang meneliti dengan tidak menyesuaikan dengan bidang keilmuan manajemen pendidikan. Hasil temuan yang diperoleh terkait ketidaksesuaian tersebut lebih mengarah pada bidang keilmuan lain karena meneliti tentang keterampilan bahasa. Masalah tersebut tidak terlalu menyentuh aspek manajemen, tetapi lebih mengarah pada bidang keilmuan bahasa karena terkait dengan keterampilan berbahasa. Rismen (2015) menyatakan bahwa kesulitan tertinggi yang dialami mahasiswa adalah menuangkan ide-ide ke dalam tulisan ilmiah. Namun, hasil penelitian ini menunjukkan bahwa secara umum, mahasiswa Program Studi Magister Manajemen Pendidikan Islam Pascasarjana UIN Alauddin Makassar sudah memahami bidangbidang keilmuan manajemen pendidikan yang tercermin pada kajian penelitian yang dilakukannya.

Dasar Pemilihan Bidang Kajian Riset Mahasiswa Program Studi Magister Manajemen Pendidikan Islam Pascasarjana UIN Alauddin Makassar

Manajemen pendidikan Islam sebagai salah satu program studi magister pada Pascasarjana UIN Alauddin Makassar merupakan program studi yang bertujuan untuk mencetak para lulusan agar mampu menguasai bidang-bidang manajemen pendidikan Islam yang relevan dengan lembaga pendidikan, baik di bawah naungan pemerintah maupun swasta. Manajemen Pendidikan Islam sebagai program studi yang berdiri sendiri tentu memiliki ruang lingkup dan bidang kajian tersendiri sehingga sangat diharapkan mahasiswa program studi ini dapat memilih tema penelitiannya dengan tidak keluar dari bidang kajian keilmuan manajemen pendidikan Islam. 
Dasar pemilihan bidang kajian riset mahasiswa Program Studi Magister Manajemen Pendidikan Islam di Pascasarjana UIN Alauddin Makassar dapat diidentifikasi melalui konfirmasi yang dilakukan dengan beberapa alumni yang telah menyelesaikan studinya. Hasil konfirmasi tersebut memberikan gambaran bahwa dasar pemilihan bidang kajian penelitiannya meliputi: kesesuaian dengan bidang pekerjaan, berdasarkan pengalaman, berdasarkan hasil bacaan, dan yang sifatnya general atau penentuan yang didasarkan atas minatnya untuk meneliti bidang tersebut.

\section{Kesesuaian dengan Bidang Pekerjaan}

Mahasiswa Program Studi Magister Manajemen Pendidikan Islam yang terdaftar pada Pascasarjana UIN Alauddin Makassar memiliki keberagaman dari segi latar belakang, ada yang melanjutkan studinya sambil bekerja dan ada pula yang masih berstatus "mahasiswa murni" atau belum bekerja. Salah satu yang menjadi dasar pemilihan bidang kajian penelitian mahasiswa adalah kesesuaiannya dengan bidang pekerjaan mereka. Dasar penentuan bidang kajian tersebut teridentifikasi melalui hasil konfirmasi yang dilakukan pada beberapa alumni yang menjadi sampel, seperti diungkapkan oleh beberapa alumni bahwa "Penelitian yang kami lakukan berangkat dari kegelisahan kami sebagai kepala sekolah/madrasah dan guru terhadap masih banyaknya masalah-masalah yang timbul dalam proses pendidikan di sekolah dan madrasah". Masalah-masalah yang dimaksudkan dalam kutipan wawancara tersebut adalah masalah pengelolaan sekolah yang dilakukan oleh kepala sekolah dan pengelolaan pembelajaran yang dilakukan oleh guru. Selain itu, terdapat pula kutipan wawancara dengan alumni yang meneliti di luar lembaga pendidikan dengan mengemukakan bahwa "Penentuan bidang kajian penelitian saya tentukan atas dasar pengamatan terhadap karakteristik pegawai yang beraneka ragam di lingkungan tempat kerja saya yang menyebabkan adanya sekatsekat antar pegawai, sehingga melahirkan kondisi lingkungan kerja yang kurang kondusif".

Hasil wawancara yang dilakukan memberikan gambaran bahwa beberapa mahasiswa menentukan bidang kajian dengan didasarkan atas kesesuaian dengan bidang pekerjaan mereka. Dasar pemilihan bidang kajian yang dilakukan tersebut memberikan kontribusi bagi dirinya pribadi sebagai pegawai/guru dan juga terhadap rekan-rekannya. Kontribusi terpenting yang dirasakan adalah bertambahnya pemahaman mereka, baik secara konseptual maupun secara praktis terkait dengan permasalahan yang menjadi bidang kajian pada penelitiannya yang sesuai dengan bidang pekerjaan yang digeluti.

\section{Pemilihan Atas Dasar Pengalaman}

Penentuan bidang kajian penelitian mahasiswa juga tidak terlepas dari pengalaman yang mereka rasakan, baik di tempat kerja maupun diperoleh melalui hasil membaca dan terinspirasi melalui proses perkuliahan yang diikuti. Dasar penentuan bidang kajian tersebut teridentifikasi melalui hasil konfirmasi yang 
dilakukan pada beberapa alumni yang menjadi sampel. Kutipan wawancara dengan beberapa alumni menyatakan bahwa "Berbagai fenomena yang diterapkan di sekolah/madrasah semakin tampak kesenjangannya setelah kami memahami konsep yang dipelajari di bangku perkuliahan. Dengan demikian, kami dapat menentukan tema dan bidang kajian penelitian berdasarkan pengalaman di lingkungan kerja dengan harapan dapat melahirkan rekomendasi konstruktif terhadap perbaikan sistem pengelolaan di tempat kerja kami”. Terdapat pula kutipan wawancara dengan alumni yang mendapatkan ide tentang tema dan bidang kajian penelitiannya dalam proses perkuliahan dengan menyatakan bahwa "Saat proses perkuliahan, banyak informasi-informasi yang disampaikan oleh dosen pada materimateri perkuliahan yang dapat dijadikan sebagai dasar untuk menentukan tema dan bidang kajian penelitian".

Hasil wawancara yang dilakukan memberikan gambaran bahwa beberapa mahasiswa menentukan bidang kajian dengan didasarkan atas pengalaman mereka, baik di tempat kerja maupun pengalamannya saat mengikuti perkuliahan. Pengalaman sebagai salah satu alasan mahasiswa menentukan bidang kajian penelitiannya akan memberikan keuntungan tersendiri bagi dirinya karena akan dirasakan secara langsung dan dapat berguna bagi pengembangan kompetensinya sebagai guru maupun kepala madrasah dalam mengelola tugas-tugasnya. Berbeda halnya ketika penentuan bidang kajian penelitian bukan atas dasar pengalaman yang menjadi minatnya karena akan berdampak pada kurangnya motivasi untuk menyelesaikan penelitiannya dan akan kurang bermanfaat bagi pengembangan dirinya.

\section{Penentuan Bidang Kajian secara Umum}

Pemilihan bidang kajian yang dimaksudkan secara umum adalah penentuan yang tidak didasarkan oleh bidang pekerjaan atau pengalaman kerja, tetapi ditentukan berdasarkan kepekaan dan sensitivitas mahasiswa dalam melihat fenomena yang akan dijadikan sebagai bidang kajian penelitiannya, dan juga didasarkan bukan atas keinginannya. Proses penentuan judul sebagai bidang kajian mahasiswa sangat beragam, sebagaimana yang telah dikemukakan sebelumnya karena atas dasar kesesuaian bidang pekerjaan, berdasarkan pengalaman, dan bahkan tidak jarang juga ditemukan mahasiswa yang bidang kajian penelitian yang diteliti bukan atas dasar keinginannya. Penentuan bidang kajian yang sifatnya general atau tidak ditentukan atas dasar kesesuaian bidang pekerjaan atau pengalaman kerja mereka juga tidak sedikit. Informasi tersebut diperoleh melalui wawancara dengan beberapa alumni yang menyatakan bahwa "Penentuan tema dan bidang kajian penelitian pada awalnya kami tentukan berdasarkan keinginan dan ketertarikan kami pada suatu fenomena. Akan tetapi, pada proses pembimbingan dan koreksian dari penguji, kami diarahkan untuk memodifikasi judul sehingga penelitian yang kami lakukan berbeda dengan rancangan awal kami". 
Asmawan (2016) menyatakan bahwa dosen pembimbing dalam menjalankan tugasnya seharusnya mempermudah atau memberikan solusi pada mahasiswanya, tetapi pada kenyataannya banyak mahasiswa yang mempunyai anggapan bahwa pada waktu bimbingan dosen pembimbing sulit ditemui, kurang komunikasi, dan kadang tidak mau menjelaskan mana yang salah atau perlu dikoreksi. Beberapa alumni yang masih berstatus "mahasiswa murni" saat kuliah menyatakan bahwa "Rancangan penelitian yang kami tetapkan didasarkan pada ketertarikan kami untuk meneliti fenomena-fenomena yang terjadi di lembaga pendidikan untuk membandingkan antara realitas dengan konsep-konsep yang telah kami pelajari".

Hasil wawancara yang dilakukan pada beberapa sampel menunjukkan adanya penentuan bidang kajian bukan atas dasar keinginan mahasiswa, tetapi atas dasar arahan promotor saat konsultasi. Selain itu, terdapat juga pemilihan bidang kajian atas dasar keinginan atau ketertarikannya semata untuk meneliti masalah-masalah yang terjadi di lapangan (lembaga pendidikan, maupun pada instansi lain). Pemilihan tema penelitian yang sifatnya general ini banyak dilakukan oleh mahasiswa yang belum memiliki pekerjaan sehingga mereka menetapkan bidang kajian penelitian atas dasar sensitivitas dan minatnya untuk melakukan penelitian pada tema-tema atau variabel-variabel tertentu.

Berbagai penelitian yang dilakukan mahasiswa Program Studi Magister Manajemen Pendidikan Islam Pascasarjana UIN Alauddin Makassar menunjukkan bahwa mahasiswa memiliki kecenderungan dan dasarnya dalam menentukan tema, jenis, metode, dan bidang kajian penelitiannya masing-masing. Wendra, dkk. (2014) menyampaikan bahwa "Hambatan sebagian besar mahasiswa dalam menyelesaikan studinya di perguruan tinggi di antaranya disebabkan oleh kesulitan menyusun karya ilmiah (skripsi, tesis, disertasi)". Proses penyusunan karya ilmiah tidak terlepas dari berbagai faktor, baik faktor internal maupun faktor eksternal. Hal tersebut juga dikemukakan oleh Asmawan (2016) bahwa terdapat dua faktor yang menghambat mahasiswa dalam menyelesaikan tugas akhirnya, yaitu faktor internal yang berasal dari mahasiswa itu sendiri dan faktor eksternal, seperti lingkungan, sistem pengelolaan oleh prodi, dan dosen pembimbing. Akan tetapi, Mahasiswa Program Studi Magister Manajemen Pendidikan Islam Pascasarjana UIN Alauddin Makassar telah mampu menghasilkan karya tulis (tesis) dengan kecenderungannya masing-masing yang disesuaikan dengan bidang kajian manajemen pendidikan Islam.

\section{PENUTUP/SIMPULAN}

Kecenderungan riset mahasiswa Program Studi Magister Manajemen Pendidikan Islam Pascasarjana UIN Alauddin Makassar: (1) Dari segi tema penelitian lebih cenderung pada tema sekolah, madrasah dan pesantren; (2) Dari segi bidang kajian, mahasiswa lebih cenderung pada bidang kajian perilaku organisasi, manajemen berbasis sekolah, dan kepemimpinan; (3) Dari segi metodologi penelitian terkait jenis 
penelitian, mahasiswa lebih cenderung memilih penelitian dengan pendekatan kualitatif. Mahasiswa Program Studi Magister Manajemen Pendidikan Islam Pascasarjana UIN Alauddin Makassar telah menyesuaikan bidang kajian penelitiannya dengan bidang keilmuan manajemen pendidikan. Dasar penentuan tema bidang kajian mahasiswa didasari atas kesesuaiannya dengan bidang pekerjaan, pengalaman (baik pengalaman dalam perkuliahan maupun dalam lingkungan kerja), serta penentuan yang sifatnya umum.

Hasil penelitian ini diharapkan berimplikasi pada perbaikan sistem penyusunan tugas akhir mahasiswa S2 Program Studi MPI Pascasarjana UIN Alauddin Makassar dengan meningkatkan pembinaan mahasiswa pada saat perkuliahan agar termotivasi untuk lebih banyak melakukan riset yang memberi inovasi dalam penyelenggaraan manajemen pendidikan, baik di tingkat makro, meso, maupun mikro. Selain itu, proses pengajuan judul dalam sebuah diskusi di bawah Lembaga Pembina Akademik serta pemantauan pelaksanaan riset oleh dewan promotor.

\section{DAFTAR PUSTAKA}

Ardiansyah, Adly, M. A., dan Rangkuti, A. (2013). Kecenderungan Penelitian Skripsi Mahasiswa Jurusan Perbandingan Hukum dan Mazhab Fakultas Syari'ah IAIN SU [Institut Agama Islam Negeri Sumatera Utara]. https://phmiainsu.blogspot.com/2015/01/kecenderungan-penelitian-skripsi.html

Asmawan, M. C. (2016). Analisis Kesulitan Mahasiswa Menyelesaikan Skripsi. Jurnal Pendidikan IImu Sosial, 26(2), 51-57. http://journals.ums.ac.id/index.php/jpis/article/download/3331/2178

Bungin, B. (2014). Metode Penelitian Kuantitatif: Komunikasi, EKonomi, dan Kebijakan Publik serta IImu-IImu Lainnya. Jakarta: Kencana.

Danial, D., dan Damopolii, M. (2019). Hubungan antara Budaya Madrasah dengan Motivasi Kerja Guru di MTs se-Kecamatan Sinjai Barat. Lentera Pendidikan, 22(1), 141-156. https://doi.org/https://doi.org/10.24252/Ip.2019v22n1i12

Furchan, A. (2007). Pengantar Penelitian dalam Pendidikan. Jakarta: Pustaka Pelajar.

Mahmud. (2011). Metode Penelitian Pendidikan. Bandung: Pustaka Setia.

Mardiana. (2013). Seni Menulis IImiah: Keselarasan Metode dan Gaya Belajar. Samata-Gowa: Alauddin University Press.

Misbahuddin, dan Hasan, I. (2013). Analisis Data Penelitian dengan Statistik. Jakarta: Bumi Aksara.

Nugroho, R. T. (2016). Kecenderungan Mahasiswa Pendidikan Biologi FKIP UMS dalam Melaksanakan Penelitian Skripsi Tahun 2015 [Universitas 
Muhammadiyah

Surakarta].

https://core.ac.uk/download/pdf/148610447.pdf

Prahmana, R. C. I., Kusumah, Y. S., dan Darhim, D. (2016). Keterampilan Mahasiswa dalam Melakukan Penelitian Pendidikan Matematika melalui Pembelajaran Berbasis Riset. Beta Jurnal Tadris Matematika, 9(1), 1. https://doi.org/10.20414/betajtm.v9i1.8

Pujiyanto, dan Suyoso. (2011). Analisis Kecenderungan dan Tren Penelitian pada Mahasiswa Pendidikan Fisika sebagai Revitalisasi Bidang Keahlian Penunjang Akreditasi: Studi Kasus Prodi Pendidikan Fisika FMIPA UNY. Prosiding Seminar Nasional Sains 2011: Menggunakan Sains Sebagai Sarana Untuk Pembelajaran Kepribadian. http://staffnew.uny.ac.id/upload/132302519/penelitian/Analisis+Kecende rungan+dan+Tren+Penelitian+Pada+Mahasiswa $+\ldots . . p d f$

Rahman, D., dan Husain, A. (2020). Motivasi Kerja Guru: Hubungan Realitas Iklim dan Budaya dengan Motivasi Kerja Guru Madrasah. Sidoarjo: Nizamia Learning Center.

Rismen, S. (2015). Analisis kesulitan mahasiswa dalam penyelesaian skripsi di Prodi Pendidikan Matematika STKIP PGRI. Lemma, I(2), 57-62. ejournal.stkip-pgrisumbar.ac.id/index.php/jurnal-lemma/article/view/538

Saat, S., dan Mania, S. (2019). Pengantar Metodologi Penelitian: Panduan bagi Peneliti Pemula. Gowa: Pusaka Almaida.

Saebani, B. A. (2017). Pedoman Aplikatif Metode Penelitian dalam Penyusunan Karya IImiah, Skripsi, Tesis, dan Disesrtasi. Bandung: Pustaka Setia.

Sugiyono. (2016). Metode Penelitian Kuantitatif, Kualitatif, dan R\&D. Bandung: Alfabeta.

Sukmadinata, N. S. (2013). Metode Penelitian Pendidikan. Bandung: Remaja Rosdakarya.

Suryabrata, S. (2016). Metodologi Penelitian. Jakarta: Raja Grafindo Persada.

Wendra, I. W., Sutama, I. M., dan Wisudariani, N. M. (2014). Pembahasan Hasil Penelitian dalam Skripsi Mahasiswa Jurusan Pendidikan Bahasa dan Sastra Indonesia UNDIKSHA. JPI (Jurnal Pendidikan Indonesia), 3(2), 411-424. https://doi.org/10.23887/jpi-undiksha.v3i2.4458

Yusuf, A. M. (2014). Metode Penelitian Kuantitatif, Kualitatif dan Penelitian Gabungan. Jakarta: Kencana. 